\title{
Author Correction: Deglacial water-table decline in Southern California recorded by noble gas isotopes
}

\author{
Alan M. Seltzer (1), Jessica Ng, Wesley R. Danskin (1), Justin T. Kulongoski, Riley S. Gannon (1), Martin Stute \& \\ Jeffrey P. Severinghaus
}

Correction to: Nature Communications https://doi.org/10.1038/s41467-019-13693-2, published online 16 December 2019.

The original version of the Supplementary Information associated with this Article included an incorrect Supplementary Data file, in which, the second sheet of the Excel workbook had misaligned sample IDs with corresponding data. The HTML has been updated to include a corrected version of Supplementary Data; the original incorrect version of Supplementary Data can be found as Supplementary Information associated with this Correction.

Published online: 03 August 2021

\section{Additional information}

Supplementary information The online version contains supplementary material available at https://doi.org/10.1038/s41467-021-24923-x. \begin{abstract}
reproduction in any medium or format, as long as you give appropriate credit to the original author(s) and the source, provide a link to the Creative Commons license, and indicate if changes were made. The images or other third party material in this article are included in the article's Creative Commons license, unless indicated otherwise in a credit line to the material. If material is not included in the article's Creative Commons license and your intended use is not permitted by statutory regulation or exceeds the permitted use, you will need to obtain permission directly from the copyright holder. To view a copy of this license, visit http://creativecommons.org/licenses/by/4.0/.
\end{abstract}

(c) Open Access This article is licensed under a Creative Commons Attribution 4.0 International License, which permits use, sharing, adaptation, distribution and

(c) The Author(s) 2021 